\title{
ANALISIS PENGGUNAAN FERMENTASI PROBIOTIK PADA PAKAN TERHADAP PRODUKTIFITAS UDANG VANAME (Litopenaeus vannamei)
}

\author{
Analysis of The Use of Probiotic Fermentation in Feed on The Production of Vaname Shrimp (Litopenaeus vannamei)
}

\author{
Agus Wijayanto ${ }^{1}$ Hadijah $^{2}$, Sri Mulyani ${ }^{2}$ \\ ${ }^{1}$ PT. Universal Agri Bisnisindo, Makassar, \\ ${ }^{2}$ Program Studi Budidaya Perairan Program Pascasarjana Universitas Bosowa \\ Email : awijayanto638@gmail.com
}

Diterima: 03 Maret 2020

Dipublikasikan: 05 Juni 2020

\begin{abstract}
ABSTRAK
Beberapa tahun terakhir pembudidaya udang Vaname sudah meninggalkan penggunaan antibiotik untuk membantu mengatasi penyakit dalam upaya meningkatkan hasil panen, karena terbukti penggunaan bakteri menjadi semakin meningkatkan resistensi bakteri patogen terhadap antibiotik. Probiotik menjadi solusi terbaik saat ini untuk mendapatkan keberhasilan optimal pada hasil produksi budidaya udang Vaname. Tujuan dari penelitian ini supaya memperoleh pengetahuan konsentrasi terbaik penggunaan probiotik yang diberikan dengan pencampuran pakan dengan berbeda konsentrasi untuk pertumbuhan, sintasan dan FCR udang vaname (Litopenaeus vannamei). Metode yang digunakan pada penelitian ini eksperimental yang terdiri atas 4 perlakuan yaitu A (tanpa penambahan probiotik fermentasi pada pakan), B (penambahan probiotik fermentasi 0,5 liter), C (pakan dengan Probiotik fermentasi 1 liter), dan P3 (pakan dengan Probiotik fermentasi 1,5 liter) pada wadah dengan kepadatan 100 ekor/L. Hasil penelitian menunjukkan rata-rata laju pertumbuhan spesifik udang Vaname berkisar antara 0.16-0,26 \%, tingkat kelangsungan hidup berkisar antara $49-93 \%$.
\end{abstract}

Kata Kunci: Udang, Vaname, Probiotik, Fermentasi, Pertumbuhan

\section{ABSTRACT}

In the last few years, vaname shrimp farmers have abandoned the use of antibiotics to help overcoming the disease as an effort to increase crop yields, because it is proven that the use of bacteria has increased the resistance of pathogenic bacteria to antibiotics. Probiotics are the best solution at this time to obtain optimal success in the production of vaname shrimp. The purpose of this study is to obtain the best concentration of probiotic use given by mixing feed with different concentrations for growth, survival and FCR of vaname shrimp (Litopenaeus vannamei). The method used in this experimental study consisted of 4 treatments namely $A$ (without addition of fermented probiotics in feed), B (addition of 0.5 -liter fermented probiotics), $C$ (feed with 1-liter fermented probiotics), and P3 (feed with 1.5-liter fermented probiotics) in containers with a density of 100 ind./L. The results showed that the average specific growth rate of vaname shrimp ranged from 0.16 to $0.26 \%$ and the survival rate ranged from 49 to $93 \%$.

Keywords: Shrimp, Vaname, Probiotic, Fermentation, Growth

\section{PENDAHULUAN}

Udang Vaname (Litopenaeus vannamei) memiliki keunggulan diantara komoditas udang air payau yang sudah berhasil dikembangkan budidayannya, beberpa kelebihan udang ini adalah kemampuan beradaptasi terhadap perubahan lingkungan, pertumbuhan yang cepat dan bisa dibudidayakan dengan kepadatan tinggi baik pada tambak tradisional maupun intensive. Arsad dkk, (2017) mengatakan budidaya udang di tambak membutuhkan parameter lingkungan optimal baik fisik, kimia dan biologi. Namun faktor lingkungan tersebut masih belum mampu menstabilkan hasil produksi para pembudidaya apalagi dengan kerusakan ekosistem yang terjadi di sekitar lingkungan budidaya yang juga diakibatkan oleh kegiatan budidaya itu sendiri merupakan faktor utama penyebab rentannya budidaya udang dari serangan penyakit (Adiwijaya dkk, 2003) dan (Kordi dan Tancung 2007). Salah satu upaya potensial dalam mengatasi penyakit sekaligus peningkatan produksi pada budidaya udang vaname di tambak adalah penggunaan probiotik. (Decamp dan Moriarty 2007). Probiotik mengandung konsorsium dari beberapa kelompok bakteri, diantaranya kelompok bakteri perombak bahan organik yang memiliki peran sebagai proteolitik dan aminolitik yang mampu meningkatkan penyerapan nutrisi pakan sehingga pertumbuhan udang lebih cepat, kelompok bakteri nitrifikasi yang dapat memperbaiki ekosistem perairan karena kemampuannya mengubah amoniak yang bersifat racun bagi udang menjadi nitrat yang tidak berbahaya, dan kelompok bakteri asam laktat yang berperan dalam meningkatkan nafsu makan udang, memproduksi antibiotik, dan meningkatkan respon imun terhadap berbagai bakteri yang bersifat pathogen (Budi dan Zainuddin, 2012). Ber-dasarkan uraian latar belakang ini maka memerlukan pe-nelitian penggunaan bakteri dengan perlakuan fermentasi yang berbeda dengan pencampuran pada pakan untuk mengetahui produktifita yang digambarkan dalam laju pertumbuhan harian dan tingkat kehidupan udang vaname (Litopenaeus vannamei). 


\section{METODE PENELITIAN}

Tempat dan Waktu

Penelitian dilakukan dengan menggunakan fasilitas Balai Perikanan Budidaya Air Payau (BPBAP) Takalar dan untuk analisa laboratorium menggunakan fasilitas Laboratorium $\mathrm{Nu}-$ trisi dan Penyakit BPBAP yang berlangsung dari bulan Mei hingga Juli 2019.

\section{Metode penelitian}

Penelitian ini dilakukan dengan metode eksperimental. Komoditas yang diujikan adalah benih udang vaname (Litopenaeus vannamei) PL/post larva 10. Pakan uji yang digunakan yaitu pakan komersial dengan komposisi kandungan Lemak $5 \%$, Protein $30 \%$, Serat $8 \%$, Air $12 \%$, dan Abu $13 \%$ yang telah diberi fermentasi probiotik sesuai perlakuan pada penelitian. Pakan diberikan dengan frekwensi 4 kali sehari dengan menggunakan dosis sebanyak 3-5\% bobot tubuh udang setelah dilakukan pengukuran tiap harinya. Penelitian ini dengan metode RAL dengan 4 perlakuan dan 3 ulangan, yaitu:

- Perlakuan $\mathrm{P} 0=$ tidak memakai probiotik pada $1 \mathrm{~kg}$ Pakan komersil

- Perlakuan P1 = Probiotik 0,5 ltr pd pakan

- Perlakuan P2 = Probiotik 1 ltr pd pakan

- Perlakuan P3 = Probiotik 1,5 ltr pd pakan

\section{Parameter Uji}

\section{LPS (Laju pertumbuhan spesifik)}

Laju pertumbuhan spesifik merupakan parameter untuk mengamati tingkat pertumbuhan dan presentase pemambahan bobot harian (Effendie, 1997).

$$
\mathrm{LPS}=\frac{\ln W t-\ln W o}{t} \times 100 \%
$$

dimana:

LPS = Laju pertumbuhan spesifik (g/day)

$\mathrm{Wt}=$ Bobot rata-rata ikan hari ke-t $(\mathrm{g})$

Wo $=$ Bobot rata-rata awal penelitian $(\mathrm{g})$

$\mathrm{T}=$ Waktu penelitian (hari)

\section{Kelangsungan Hidup}

Jumlah kelangsungan hidup udang penelitian dihitung pada masing-masing wadah penelitian saat akhir kegiatan (Effendi, 1997) dengan formula sebagai berikut:

$\mathrm{SR}=\frac{N t}{N o} x 100 \%$

dimana:

$\mathrm{SR}=$ Kelangsungan hidup $(\%)$

$\mathrm{Nt} \quad=$ Jumlah udang uji pada akhir penelitian

No = Jumlah udang uji pada awal penelitian.

\section{Analisa Data}

Analisa data menggunakan exel dan ditunjukkan dalam bentuk tabel dan grafik dan akan dilanjutkan Anova dan bila hasilnya menunjukkan beda nyata akan dilanjutkan dengan Uji W-Tukey untuk memperoleh Laju pertumbuhan harian dan kelangsungan hidup udang yang diujikan.

\section{HASIL DAN PEMBAHASAN}

Hasil pengamatan laju pertumbuhan udang vanname mengasilkan perbedaan nilai pada setiap perlakuan. Dimana laju pertambahan panjang dan bobot larva udang selama penelitian menunjukkan kecenderungan semakin naik seiring waktu penelitian. Nilai rata-rata laju pertambahan panjang dapat dilihat pada Gambar 1 dan pertumbuhan bobot spesifik udang selama penelitian disajikan pada pada Gambar 2.

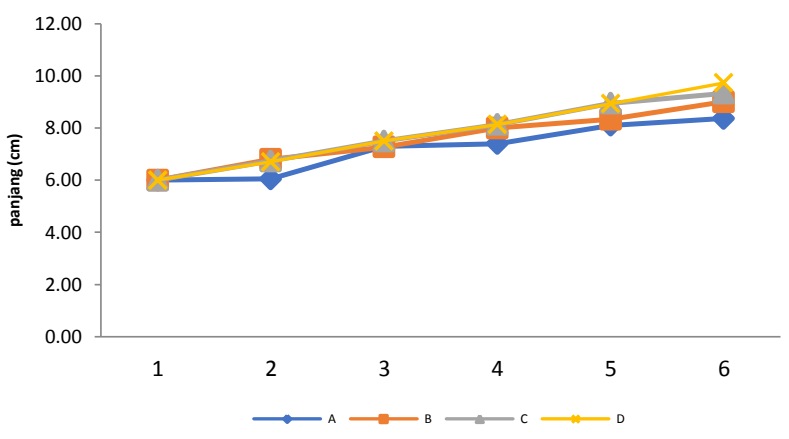

Gambar 1. Laju Pertumbuhan Panjang Udang Selama Penelitian

Panjang udang vaname tertinggi hingga hari ke- 42 terdapat pada D (1,5 liter/kg pakan) dengan nilai rata-rata panjang udang vaname sebesar $3,17 \mathrm{~cm}$ dengan standar deviasi 1,89 . Sedangkan panjang udang vaname terendah hingga hari ke-42 terdapat pada kontrol (0 liter $/ \mathrm{kg}$ pakan) dengan nilai rata-rata $2,5 \mathrm{~cm}$ dengan standar deviasi 1.0 Hasil analisa Anova menunjukkan bahwa keempat perlakuan tidak berbeda nyata pada pertambahan panjang udang $(\mathrm{P}>0,05)$.

Pertumbuhan berat spesifik pada akhir pemeliharaan, berada pada kisaran 0,16\%-0,26\%. Pertumbuhan berat menunjukkan hasil berbeda, lebih rendah dari pada perlakuan yang sama pada pakan oleh Hanafi dkk (2006), dengan hasil $9.52 \%$, Hendrajat dkk (2008) dengan $9.09 \%$. Hal ini kemungkinan disebabkan kepadatan perlakuan yang berbeda dimana pada penelitian penelitian terdahulu dengan jumlah kepadatan $6-9$ ekor/m sedangkan pada penelitian ini 100 ekor/m.

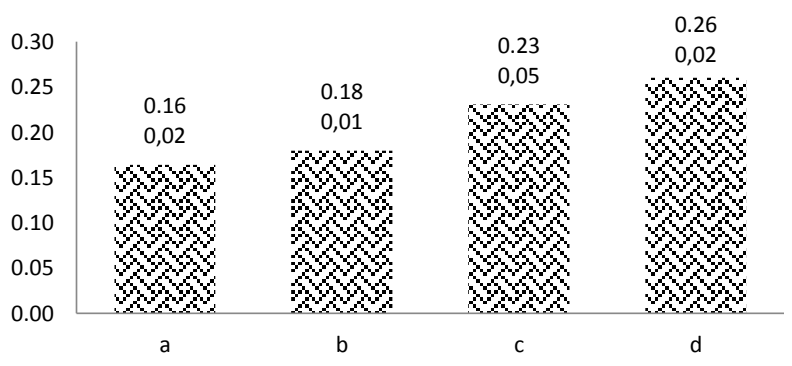

Gambar 2. Pertumbuhan Bobot Spesifik Perlakuan Probiotik Fermentasi

Hasil Anova memberikan gambaran perbedaan signifikan keempat perlakuan terhadap pertumbuhan udang dengan nilai F hitung sebesar 10,487 dengan tingkat standar deviasi tertinggi pada perlakuan $\mathrm{C}$ sebesar 0,05 . Pada hasil uji lanjut Tukey menunjukkan bahwa perlakuan kontrol dengan konsentrasi probiotik 1,5 ltr tidak berbeda nyata. Yang berbeda adalah kontrol dan perlakuan 0,5 dengan perlakuan 1 dan 1,5 liter. 


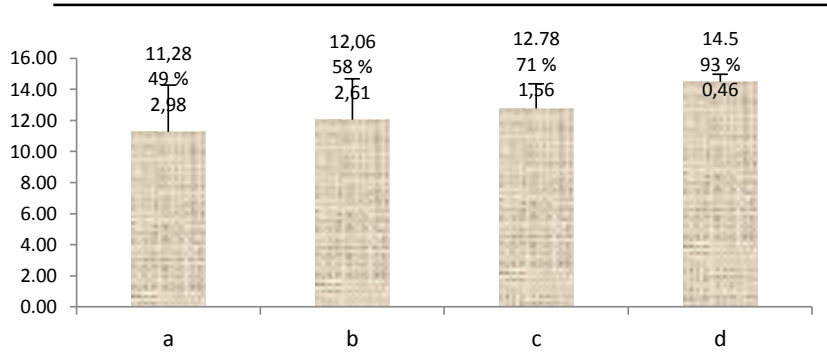

Gambar 3. Rerata dan Standar deviasi Kelangsungan Hidup Udang dengan probiotik fermentasi.

Pada Gambar 3, menunjukkan nilai tingkat kelangsungan hidup udang yang semakin tinggi bila dilakukan pemberian probiotik yang difermentasi dengan standar deviasi paling rendah sebesar 0,46 . Hal ini diduga pengaruh dari proses metabolisme udang yang semakin baik dengan terserapnya pakan yang sudah terfermentasi dengan probiotik sesuai dengan pendapat Manoppo (2011) pakan yang mengandung probiotik yang baik akan meningkatkan kelangsungan hidup udang. Dalmin dkk (2001) menambahkan pemberian probiotik mam$\mathrm{pu}$ mendominasi bakteri menguntungkan sehingga memberikan kelulus hidupan 100\% pada udang. Citria dkk, 2018, mengatakan pemberian probiotik mampu menekan partumbuhan bakteri dan merangsang perkembangan sel sel hemosit, dimana dengan jumlah sel hemosit yang meningkat akan mampu memberikan pertahanan tubuh udang dalam melawan infeksi bakteri Suwoyono dan Mangampa, (2010), karena kurangnya daya tahan tubuh bakteri Vibrio $s p$ akan membuat udang stress, kurang nafsu makan dan menghancurkan heaptopankreas sehingga udang akan mengalami kematian (Atmosumarsono dan Nurbaya 2005).

\section{KESIMPULAN}

Penambahan probiotik fermentasi pada pakan terbukti meningkatkan jumlah pertumbuhan panjang spesifik tertinggi 3,17 dan pertumbuhan bobot $0,26 \%$ serta memberikan tingkat kelangsungan hidup udang vaname 93\%, Selanjutnya Dosis terbaik probiotik fermentasi yang diaplikasikan pada pemeliharaan juvenile udang vaname dengan padat tebar 100 ekor/m2 adalah 1,5 liter/kg pakan.

\section{DAFTAR PUSTAKA}

Adiwijaya, D., Sapto, P.R., Sutikno, E.,Sugeng., Subiyanto. (2003). Budidaya Udang Vaname (Litopenaeus vannamei) Sistem Tertutup yang Ramah Lingkungan. Departemen Kelautan dan Perikanan, Balai Besar Pengembangan Budidaya Air Payau, Jepara, 29 hlm.

Arsad, S., Ahmad. A, Atika. P.P, Betrina. M.V, Dhira. K.S, dan N.R. Buwono.2017. Study kegiatan Budidaya Pembesaran Udang Vaname (Litopenaeus vannamei) dengan Penerapan Sistem Pemeliharaan Berbeda. Jurnal Ilmiah Perikanan dan Kelautan 9(1): 1-14.
Atmomarsono M, Muliani \& Nurbaya. 2005. Pengaruh Komposisi Jenis Bakteri Probiotik Terhadap Kualitas Air Dan Sintasan Pasca Larva Udang Windu Pada Skala Laboratorium dalam Rachmansyah A. Sudaryono D. Yaniharto M. Nadjib \& Purnomo. Prosiding konferensi Nasional Akuakultur. Makasar : 23- 25.

Budi, S., \& Zainuddin, Z. (2012). Peningkatan Asam Lemakrotifer Brachionus Plicatilis Dengan Periode Pengkayaan Bakteri Bacillus Sp. Berbeda. Octopus: Jurnal Ilmu Perikanan, 1(1), 1-5.

Budi, S., \& Aslamsyah, S. (2011). Improvement of the Nutritional Value and Growth of Rotifer (Brachionus plicatilis) by Different Enrichment Period with Bacillus sp. Jurnal Akuakultur Indonesia, 10(1), 67-73.

Dalmin GK, Kathiresan K \& Purushothama A. 2001. Effect of Probiotics on Bacteria Population and Health Status of Shrimp in Culture Pond Ecosysten. Indian J Exp Biol 39: 930-942.

Decamp O \& Moriarty D. 2007. Aquaculture Spesies Profit from Probiotics. Feed Mix 15: 20-23.

Effendi, I. 1997. Biologi Perikanan. Yayasan Pustaka Nusantara. Yogyakarta

Hanafi, A., Haryanti, Zafran. Tridjoko, Sumiarsa, G., Rachmansyah, \& Insan, I 2007. Aplikasi Probiotik Dalam Budidaya Udang Intensif. Prosiding Seminar Nasional Breeding, Genetika dan bioteknologi perikanan. Pusat riset perikanan budidaya Kuta-Bali. 12 November 2007:93-104.

Hendrajat, A.E., M. Mangampa., H. Suryanto. 2007. Budidaya Udang Vannamei Pola Tradisional Plus di Kabupaten Maros Sulawesi Selatan. Media Akuakultur .2 (2):4.

Kordi, M. G. H. K., dan A. B. Tancung. 2007. Pengelolaan Kualitas Air dalam Budidaya Perairan. Rineka Cipta, Jakarta. $210 \mathrm{hlm}$.

Manoppo H. 2011. Peran Nukleotidase Sebagai Imunostimulan Terhadap Respon Imun Nonspesifik dan Resistensi Udang Vaname (Litopenaeus vannamei) [Skripsi]. Bogor: IPB.

Suwoyono, H. S. dan Mangampa, M. (2010). Aplikasi Probiotik dengan Konsentrasi Berbeda pada Pemeliharaan Udang Vannamei (Litopaneous Vannamei).RisetBalai Perikanan Budidaya Air Payau.ulawesi Selatan :239-347. 